\title{
Comparison of Growth and Yield Characteristics of BARI Tomato Varieties
}

\author{
M. Biswas ${ }^{1}$, D. R. Sarkar $^{2}$, M. I. Asif ${ }^{3}$, R. K. Sikder $^{4}$, H. Mehraj ${ }^{5}$ and A. F. M Jamal \\ $\operatorname{Uddin}^{5 *}$
}

Dept. of Agriculture Extension, Ministry of Agriculture, Bangladesh ${ }^{1}$

Dept. of Soil Science ${ }^{2}$, Dept. of Seed Technology ${ }^{3}$, Dept. of Horticulture ${ }^{5}$

Sher-e-Bangla Agricultural University, Dhaka

Horticulture Development Division, BADC, Dhaka, Bangladesh ${ }^{4}$

Corresponding author* : jamal4@yahoo.com

\begin{abstract}
An experiment was conducted at Agronomy Farm of the Sher-e-Bangla Agricultural University, Dhaka to study growth and yield responses of tomato varieties. Experiment consisted of four varieties, viz. BARI Tomato-4 $\left(V_{1}\right)$, BARI Tomato-5 $\left(V_{2}\right)$, BARI Tomato-7 $\left(V_{3}\right)$ and BARI Tomato-9 $\left(V_{4}\right)$ using Randomized Complete Block Design with three replications. Tallest plant $(101.3 \mathrm{~cm})$, maximum number of leaves (114.1/plant) and maximum number of branches (10.0/plant) was found from BARI Tomato-7. While maximum number of flowers (6.1/cluster), number of fruits (5.0/cluster), number of clusters (17.9/plant) were found from BARI Tomato-9. However, maximum fruit diameter $(20.1 \mathrm{~cm})$, individual fruit weight $(115.9 \mathrm{~g})$, yield $(34.7 \mathrm{~kg} / \mathrm{plot}$ and $95.9 \mathrm{t} / \mathrm{ha})$, number of locule (4.4/fruit) were also found from BARI Tomato-7. Virus infestation, fruit length and Total soluble solid (TSS) were statistically identical among the varieties.
\end{abstract}

Key words: Tomato, varieties, growth and yield

\section{Introduction}

Tomato (Solanum lycopersicum) belonging to the family Solanaceae, is one of the important, popular and nutritious vegetables grown in Bangladesh during winter season and cultivated in all parts of the country (Haque et al., 1999). Bangladesh produced 102 thousand tons of tomato in 15.8 thousand hectares of land during the year 2008-2009 and the average yield being 6.5 t/ha (BBS, 2010) which is very low in comparison with that of other countries. The yield of tomato in our country is not satisfactory enough in comparison to requirement (Aditya et al., 1999). The yield of tomato depends on numerous factors including genotype or the variety. Plant breeders have produced hundreds of tomato varieties to suit every climate, garden site and taste. Various cultivars produce fruit that range in size from small marbles to giant grapefruits (Benton, 2008). Breeding over the past 50 years has substantially changed the tomato plant and its fruit characteristics. Varieties available today for use by both the commercial and home gardener have a wide range of plant characteristics. Cultivar selection is one of the critical decisions that the commercial grower must make each season. Variety selection is a dynamic process. Some varieties may remain favorable for many years while others might be supplanted by newer cultivars after a few seasons (McAvoy and Ozores-Hampton, 2010). By this time BARI released a good number of varieties. Present experiment was conducted to find out the morphological response for higher yield of four BARI released tomato varieties. 


\section{Materials and Method}

Location of the study: Experiment was conducted at Agronomy Farm, Sher-e-Bangla Agricultural University, Dhaka, Bangladesh during October 2008 to March 2009.

Genetic materials and source: Seeds of four tomato varieties were used as planting materials. Tomato varieties used in the experiments were BARI Tomato- $4\left(\mathrm{~V}_{1}\right)$, BARI Tomato-5 $\left(\mathrm{V}_{2}\right)$, BARI Tomato-7 $\left(\mathrm{V}_{3}\right)$ and BARI Tomato-9 $\left(\mathrm{V}_{4}\right)$. Seeds were collected from the Horticulture Research Centre, Bangladesh Agricultural Research Institute (BARI) at Joydebpur, Gazipur.

Experimental design: The experiment was laid out in Randomized Complete Block Design (RCBD) with three replications. The size of unit plot was $2 \mathrm{~m} \times 1.8 \mathrm{~m}$. The distance between the blocks was $1 \mathrm{~m}$ and that between plots was $50 \mathrm{~cm}$.

Transplantation of seedlings: Healthy and uniform sized 30 day-old seedlings were taken separately from the seedbed and were transplanted in the experimental field on 28 November 2008 maintaining spacing of $60 \mathrm{~cm}$ and $50 \mathrm{~cm}$ between the rows and plants respectively.

Fertilization: Ten tones of cow dung, $150 \mathrm{~kg}$ of urea, $150 \mathrm{~kg}$ of TSP and $250 \mathrm{~kg}$ of MP per hectare were applied in the experimental plot. Entire amount of cow dung and TSP and half of MP was applied during final land preparation. The entire urea and rest of MP were applied in three equal installments at 15, 30 and 50 days after transplanting in the field.

Data collection: Data were collected on plant height, number of leaves, number of branches, number of cluster, number of flowers, number of fruits, virus infected plant, fruit length, fruit diameter, individual fruit weight, yield/plot, yield/ha, number of fruit locule and total soluble solid (TSS) content.

TSS measurement: A fruit was sliced into two halves horizontally with a sharp knife and a small quantity of juice from them was used to determine TSS in percentage with TSS meter.

Statistical analysis: Collected data were statistically analyzed using MSTAT-C statistical package programme and mean for all the treatments was calculated. Difference between treatments means were determined by Least Significance Difference (LSD) test at 5\% level of significance (Gomez and Gomez, 1984).

\section{Results and Discussion}

\section{Plant height}

Plant height increased gradually with the advancement of time and continued up to $100 \%$ flowering. Tallest plant was found from $\mathrm{V}_{3}(83.3 \mathrm{~cm})$ at $50 \%$ flowering stage while shortest from $\mathrm{V}_{4}(63.3 \mathrm{~cm})$. On the other hand tallest plant was found from $\mathrm{V}_{3}(101.3 \mathrm{~cm})$ whereas shortest from $\mathrm{V}_{4}(69.0 \mathrm{~cm})$ at $100 \%$ flowering stage (Figure 1). Haque et al. (1998) found maximum $116.6 \mathrm{~cm}$ and minimum $47.6 \mathrm{~cm}$ plants during evaluation of tomato lines. Plant height differed among the varieties of tomato due to the variation of varieties (Kallo et al., 1998; Manoj and Ragav, 1998; Olaniyi et al., 2010). Tallness, shortness and other morphological differences are varietal characteristics, which are controlled and expressed by certain genes (Fayaz et al., 2007). 


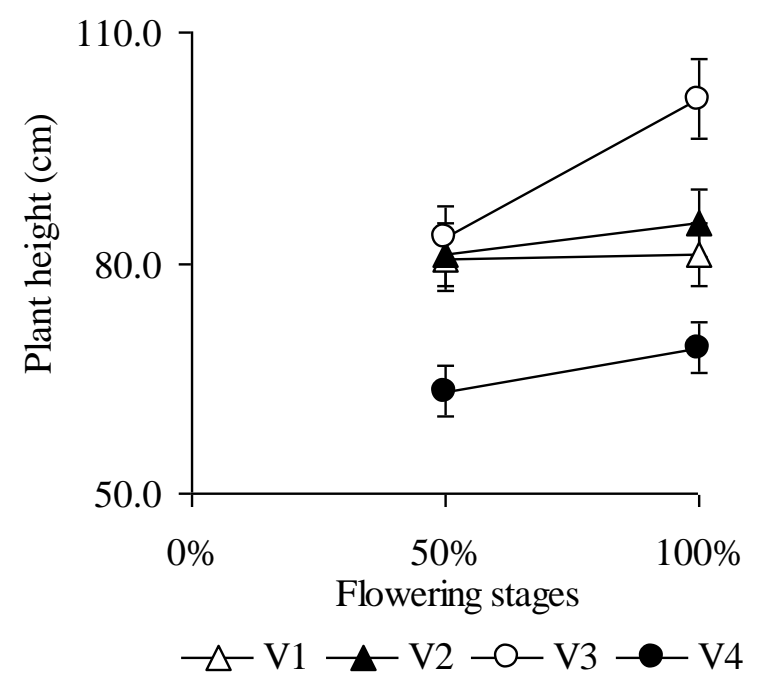

Figure 1. Varietal performance of tomato in plant height

\section{Number of leaves/plant and branches/plant}

Number of leaves/plant varied significantly among the varieties. Maximum number of leaves was found from $\mathrm{V}_{3}$ (114.1/plant) while minimum from $\mathrm{V}_{2}$ (74.0/plant). Maximum number of branches was found from $V_{3}$ (10.0/plant) while minimum from $V_{1}$ (7.3/plant) (Figure 2). Number of branches/plant varied significantly among tomato cultivars (Sharma and Rastogi, 1993).

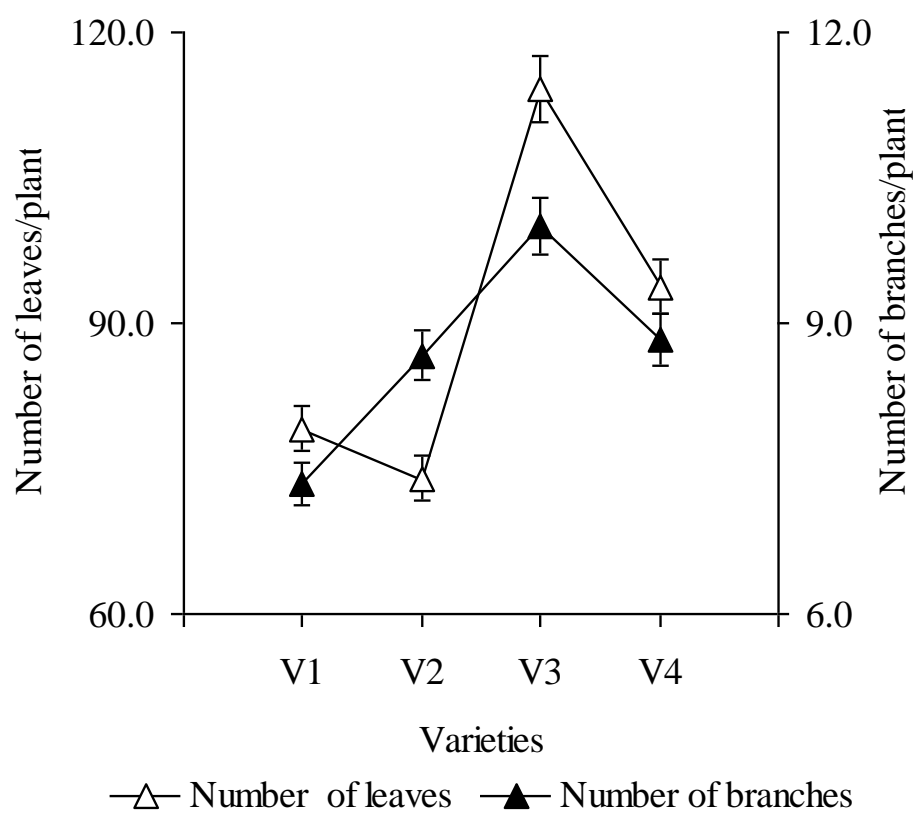

Figure 2. Performance of four tomato varieties on number of leaves and branches 


\section{Number of clusters/plant, flowers/cluster and fruits/cluster}

There was a significant difference among the varieties in the number of cluster/plant, flowers/cluster and fruits/cluster. Maximum number of clusters, flowers and fruits was found from $V_{4}$ (17.9/plant, 6.1/cluster and 5.0/cluster respectively). However, it was found that minimum number of cluster (7.4/plant) and flowers (5.4/cluster) from $V_{1}$ but fruits (4.1/cluster) from $V_{2}$ (Figure 3). Number of flowers/cluster (Zahedi and Ansari, 2012). Hussain et al. (2001) reported that tomato cvs. BARI-5 and BARI-4 produced the maximum 4.04 and 3.94 fruits/cluster.

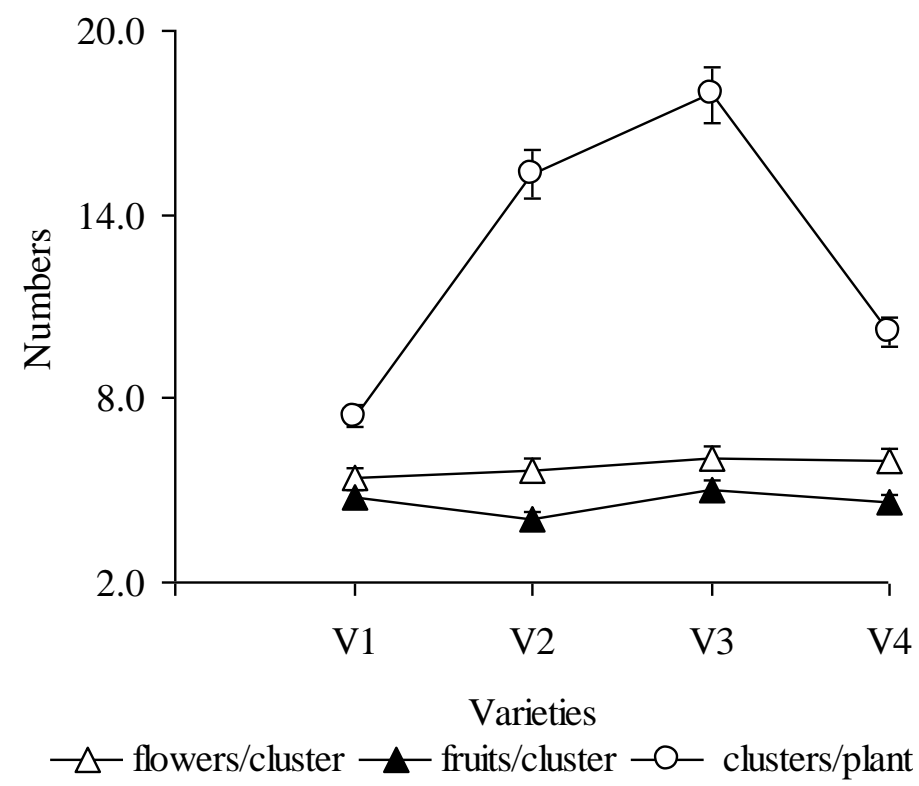

Figure 3. Performance of four tomato varieties on number of cluster/plant, flowers/cluster and fruits/cluster

\section{Virus infestation (\%)}

Virus infestation did not vary significantly among the tomato varieties. However, maximum infestation was found from $\mathrm{V}_{2}(1.9 \%)$ while minimum from $\mathrm{V}_{4}(1.4 \%)$ (Table 1). Nahiyan et al. (2014) screened of sixteen tomato genotype and reported that diseases (viral and bacterial) percentage varied $(0.0 \%$ to $66.7 \%$ ) due to variation of variety.

\section{Fruit length and diameter}

Fruit length showed statistically identical and fruit diameter showed statistically significant variation among the varieties. However, longest fruit was found from $V_{3}(8.4 \mathrm{~cm})$ while shortest from $V_{2}(7.1 \mathrm{~cm})$ (Table 1). Maximum fruit diameter was found from $V_{3}(20.1 \mathrm{~cm})$ while minimum from $V_{2}(12.7 \mathrm{~cm})$ which was statistically identical with V1 $(13.4 \mathrm{~cm})$ (Table 1). Fruit length and diameter varied due to the variation of the variety (Sing and Sahu, 1998; Rahman et al., 2000; Hussain et al., 2001).

\section{Individual fruit weight, yield/plot and yield/ha}

The weight of individual fruit weight was significantly influenced by different varieties. Maximum individual fruit weight was found from $\mathrm{V}_{3}(115.9 \mathrm{~g})$ while minimum $\mathrm{V}_{2}(46.7 \mathrm{~g})$ which was statistically identical with $\mathrm{V}_{1}(49.3 \mathrm{~g})$ and $\mathrm{V}_{4}(54.0 \mathrm{~g})$ (Table 1). Wide variation among the varieties in respect of 
individual fruit weight was due to the varietal characteristics. Varietal influence on individual fruit weight was also reported Meher et al. (1994). The different varieties of tomato significantly influenced on the yield/plot and yield/ha. Maximum yield was obtained from $\mathrm{V}_{3}(34.7 \mathrm{~kg} / \mathrm{plot})$ whereas minimum from $\mathrm{V}_{2}$ $(6.1 \mathrm{~kg} / \mathrm{plot})$ which was statistically identical with $\mathrm{V}_{1}(7.4 \mathrm{~kg} / \mathrm{plot})$ (Table 1$)$. Varietal influence on the yield of fruits per plant is also reported by Sing and Sahu (1998). Mishra and Lal (1998) found that variety Pusa Ruby gave the maximum fruit yield $(2.7 \mathrm{~kg} / \mathrm{plant})$ among the 39 tomato cultivars. Rahman et al. (2000) also reported that different tomato cultivars behaved significantly different with each other regarding yield/plot. Maximum yield was found from $\mathrm{V}_{3}(95.9 \mathrm{t} / \mathrm{ha})$ followed by $\mathrm{V}_{4}(82.3 \mathrm{t} / \mathrm{ha})$ whereas minimum from $\mathrm{V}_{2}(19.2 \mathrm{t} / \mathrm{ha})$ which was statistically identical with $\mathrm{V}_{1}(22.3 \mathrm{t} / \mathrm{ha})$ (Table 1). Ahmed et al. (1986) also reported varietal influence on the yield of fruit per hectare. Marketable yield ranged from 76.2 t/ha (Rio grande) to $37.1 \mathrm{t} / \mathrm{ha}$ (Money maker) in thirteen open pollinated cultivars and three hybrids of tomato (Rida et al., 2002).

\section{Number of locule}

Maximum number of locule was found from $V_{3}$ (4.4/fruit) while minimum from $\mathrm{V}_{2}$ (2.3/fruit) which was statistically identical with $\mathrm{V}_{1}\left(2.4 /\right.$ fruit) and $\mathrm{V}_{4}$ (2.4/fruit) (Table 1). Locule number of tomato cultivars ranged from 2 to 5 (Sarah et al., 1999) and 8 to 10 (Fehmida and Ahmad, 2007) which would imply that locule number is distinctive genetic character.

\section{Total soluble solid (TSS) content}

No significant variation in the total soluble solid content was found among the varieties. Maximum TSS content was found from $\mathrm{V}_{2}(5.4 \%)$ while minimum from $\mathrm{V}_{1}(5.0 \%)$ (Table 1). The difference among the varieties in TSS content of fruits might be due to the genetic constitution of the varieties. These results are in good agreement with the finding of Swaroop and Suryanarayana (2005) and Ahmed et al. (2007).

\section{Table 1. Varietal response of tomato to different attributes ${ }^{\mathrm{x}}$}

\begin{tabular}{|c|c|c|c|c|c|c|c|c|c|c|c|c|c|c|c|c|}
\hline $\begin{array}{c}\text { Tomato } \\
\text { varieties }\end{array}$ & $\begin{array}{c}\text { Virus } \\
\text { infected } \\
\text { plant }(\%\end{array}$ & & $\begin{array}{l}\text { Frui } \\
\text { leng } \\
(\mathrm{cm}\end{array}$ & & $\begin{array}{r}\text { Fruit } \\
\text { diamete } \\
(\mathrm{cm})\end{array}$ & & $\begin{array}{l}\text { Individu } \\
\text { fruit } \\
\text { weight ( }\end{array}$ & & $\begin{array}{r}\text { Yielc } \\
(\mathrm{kg}) / \mathrm{p}\end{array}$ & & $\begin{array}{l}\text { Yiel } \\
\text { (t)/h }\end{array}$ & & $\begin{array}{l}\text { Numb } \\
\text { of fru } \\
\text { locul }\end{array}$ & & TS & $(\%)$ \\
\hline $\mathrm{V}_{1}$ & 1.8 & $\mathrm{a}$ & 7.5 & $\mathrm{a}$ & 13.4 & $\mathrm{~b}$ & 49.3 & $\mathrm{~b}$ & 7.4 & $\mathrm{c}$ & 22.3 & $\mathrm{c}$ & 2.4 & $\mathrm{~b}$ & 5.0 & $\mathrm{a}$ \\
\hline $\mathrm{V}_{2}$ & 1.9 & $\mathrm{a}$ & 7.1 & $\mathrm{a}$ & 12.7 & b & 46.7 & b & 6.1 & $\mathrm{c}$ & 19.2 & $\mathrm{c}$ & 2.3 & b & 5.4 & $\mathrm{a}$ \\
\hline $\mathrm{V}_{3}$ & 1.5 & $\mathrm{a}$ & 8.4 & $\mathrm{a}$ & 20.1 & $\mathrm{a}$ & 115.9 & $\mathrm{a}$ & 34.7 & $\mathrm{a}$ & 95.9 & $\mathrm{a}$ & 4.4 & $\mathrm{a}$ & 5.3 & $\mathrm{a}$ \\
\hline $\mathrm{V}_{4}$ & 1.4 & $\mathrm{a}$ & 7.8 & $\mathrm{a}$ & 14.0 & $\mathrm{~b}$ & 54.0 & $\mathrm{~b}$ & 29.8 & $\mathrm{~b}$ & 82.3 & $\mathrm{~b}$ & 2.7 & b & 5.2 & $\mathrm{a}$ \\
\hline LSD 0.05 & 1.6 & & 2.0 & & 3.7 & & 10.7 & & 2.3 & & 8.0 & & 1.0 & & 1.1 & \\
\hline CV \% & 7.4 & & 3.5 & & 2.7 & & 9.6 & & 5.8 & & 7.1 & & 4.1 & & 3.2 & \\
\hline
\end{tabular}

${ }^{\mathrm{X}}$ In a column means having similar letter (s) are statistically identical and those having dissimilar letter (s) differ significantly as per 0.05 level of probability

\section{IV.Conclusion}

Growth and yield characteristics of experimented four tomato varieties varied despite of similar environmental and cultural conditions. But BARI Tomato-7 gave the best results on yield related attributes, this variety produced the highest yield (95.9 t/ha). Thus, farmers can cultivate BARI Tomato-7 among these four BARI released tomato varieties to achieve higher yield. 


\section{References}

Aditya, T. L., Rahman, L., Shah-E-Alam, M. and Ghosh, A. K. (1999). Correlation and path co-efficient analysis in tomato. Bangladesh Agril. Sci. 26(1): 119-122.

Ahmad, F., Obedullah, K., Sarwar, S., Hussain, A. and Ahmad, S. (2007). Evaluation of tomato cultivars at high altitude. Sharad J. Agriculture 23: 312-14

Ahmed, S. U., Saha, H. K., Rahman, L. and Sharfuddin, A. F. M. (1986). Performance of some advance lines of tomato. Bangladesh Hortic. 14(1):47-48.

BBS. 2010. Monthly Statistical Bulletin, June, (2010). Bangladesh Bureau of Statistics. Statistics Division, Ministry of Planning, Govt. of the People's Republic of Bangladesh, Dhaka. p. 58.

Benton J, 2008. Tomato plant culture: in the field, greenhouse, and home garden. By Taylor \& Francis Group, LLC. PP: 81-86.

Fayaz, A., Khan, O., Sarwar, S., Hussain, A. and Sher, A. (2007). Performance Evaluation of Tomato Cultivars at High Altitude. Sarhad J. Agric. 23(3): 581-585.

Fehmida, A. and Ahmad, S. D. (2007). Morphogenetic comparison of three tomato cultivars from Azad Jammu and Kashmir, Pakistan. Sarhad J. Agric. 23(2): 313-318.

Gomez, K. A. and Gomez, A. A. (1984). Statistical Procedures for Agricultural Research. 2nd edn. John Wiley and Sons. New York: 680.

Haque, M. M., Rehman, A. K. M. and Hossain, S. M. M. (1998). Physiological and yield potential of some promising tomato lines at different planting times. Pak. J. Agric. Res. 9(3): 359-362.

Haque, M. S., Islam, M. T. and Rahman, M. (1999). Studied on the Preservation of Semi-Concentrated Tomato Juice. Bangladesh J. Agril. Sci. 26(1): 37-43.

Hussain, S. I., Khokar, K. M., Mahmood, T., Mahmud, M. M. and Lagari, M. H. (2001). Yield potential of some exotic and local tomato cultivars grown for summer production. Pak. J. Biol. Sci. 4: 12151216.

Kallo, G., Chaurasia, S. N. G., Major, S. and Singh, M. (1998). Stability analysis in tomato. Vegetable Research, Ghandi Nagar, India. Vegetable Sci. 25(1): 81-84.

Manoj, R. and Raghav, M. (1998). Performance of F1 hybrids and high yielding varieties of tomato under mid-west plains of Uttar Pardesh. Progressive Hort. 30(3): 194-197.

McAvoy, G. and Ozores-Hampton, M. (2010). Cultivar selection in tomato and pepper production. University of Florida. 25(2): 38-43.

Meher, B. B., Lawande, K. E. and Joshi, V. R. (1994). Effect of different varieties and planting seasons in seed yield and yield and quality of tomato. J. Moharashtra Agric. Univ. 19(3): 393-395.

Mishra, Y. K. and Lal, S. D. (1998). Studies on varietal performance of tomato under the agro climatic conditions of U.P. hills. Progressive Hort. 30(3): 153-157.

Nahiyan, A. S. M., Momena, K., Mehraj, H., Shiam, I. H., Jamal Uddin, A. F. M. and Rahman, L. (2014). Genetic Diversity of Sixteen Tomato Varieties Grown at Sher-e-Bangla Agricultural University. Int. J. Bus. Soc. Sci. Res. 2(1): 39-44.

Olaniyi, J. O., Akanbi, W. B., Adejumo, T. A. and Akande, O. G. (2010). Growth, fruit yield and nutritional quality of tomato varieties. African J. of Food Sci. 4(6): 398-402. 
Rida, A. S., Muhammad, A. A., Ereifij, I. E. and Hussain, A. (2002). Evaluation of thirteen open pollinated cultivars and three hybrids of tomato (Lycopersicon esculentum Mill.) for yield, physiological disorders, seed production and vegetative growth. Pak. J. Agric. Res. 17(3): 290-296.

Rahman, M. A., Rashid, M. A. Rahman, A. K. M. and Hossain, M. M. (2000). Screening of wild rootstocks brinjal lines and tomato varieties against bacterial wilt. Review of progress. Activity-II. IPM-CRSP (Intrgrsted Pest Management_Collaborative Research Support Program), HRC, BARI, Gazipur, 17p.

Sarah, N. P., Holmer, R. J., Acosta, J. C. and Schnitzler, W. H. (1999). First result of tomato (Lycopersicon esculentum Miller) variety trial under urban lowland conditions. $11^{\text {th }}$ NOMCARRD regional symposium on research and developments highlights, July 28-29, 1999, Philippines.

Sharma, S. K. and Rastogi, K. B. (1993). Evaluation of some tomato cultivars for seed production under mid hill conditions of Himachal Pardesh. Annals of Agric. Res. India. 14(4): 494-496.

Singh, D. N. and Sahu, A. A. (1998). Performance of tomato cultivars in winter season on entisol of Orissa. Environ. And Ecol. 16(4): 766-762.

Swaroop, K. and Suryanarayana, M. A. (2005). Evaluation of tomato varieties and lines for growth, yield, quality and bacterial wilt resistance under coastal tropical condition of the Andaman Islands. Tropical Agriculture. 82: 294-299.

Zahedi, S. M. and Ansari, N. A. (2012). Comparison in Quantity Characters (Flowering and fruit set) of ten selected tomato (Solanum lycopersicum L.) Genotypes under subtropical climate conditions (Ahvaz). Intl. Res. J. Appl. Basic. Sci. 3(6): 1192-1197.

\section{Citation for this article (APA Style):}

Biswas, M., Sarkar, D. R., Asif, M. I., Sikder, R. K, Mehraj H. \& Jamal Uddin, A. F. M. (2015). Comparison of Growth and Yield Characteristics of BARI Tomato Varieties. Journal of Bioscience and Agriculture Research 03(01), 01-07.

Retrieved January 04, 2015, from http://www.journalbinet.com/current-issue-jbar-2.html 